\title{
Giovanni Alfonso Borelli's Last Will (1679, December 31st)
}

\section{The Graph of an Ego-Network}

\author{
Federica Favino | ORCID: 0000-0001-5090-2828 \\ Sapienza University of Rome, Rome, Italy \\ federica.favino@uniromaı.it
}

\begin{abstract}
The paper provides an annotated edition of the original copy of the last will by the mathematician, physicist, and astronomer Giovanni Alfonso Borelli (1608-1679), discovered among the papers of the Curia of the Cardinal Vicary, kept in the State Archives of Rome. Up until now, the document was known only through the incomplete copy guarded in the General Archives of the Piarists religious Order-Borelli's sole heirat the General House of San Pantaleo in Rome. The testament was found during the implementation of the Horizon 2020 Borelli Galaxy project (2018-2021, www.borgal .eu), aimed at editing a unified electronic catalogue of Borelli's correspondence and to use his letters as a source of data suitable to map and chart Borelli's overlapping intellectual, social, and political networks. The will is treated here as a "socio-text," that is, as a freeze-frame of Borelli's networks in his last years in Rome. By coding and processing - through the web infrastructure Nodegoat and the relational modes of analysis it provides - the interactions between Borelli and his heirs and legatees, as well as the interactions that occurred among his legatees outside this scope, the paper tries to reconstruct and visualize the social structure of this network, to single out Borelli's place within that complex system, as well as to figure out its genesis. Compared with Borelli's contemporary correspondence, this data also offers a glimpse into his later editorial choices.
\end{abstract}

\section{Keywords}

Giovanni Alfonso Borelli - Network Historical Research - heuristic visualization 'Galilean Piarists' - factional conflict - scientific academies 
This "unpublished document" is the last will by the renowned mathematician, physicist and astronomer Giovanni Alfonso Borelli (1608-1679). ${ }^{1}$ Up until now, the document was known only through a copy-incomplete and therefore barely legible - kept in the General Archives of the Piarists religious Order at the General House of San Pantaleo in Rome. ${ }^{2}$ The original document below lies among the papers of the Office n. $3^{2}$ of the Curia of the Cardinal Vicary, kept in the State Archives of Rome. ${ }^{3}$ The testament was found during the implementation of the Horizon 2020 Borelli Galaxy project (2018-2021), aimed at editing a unified electronic catalogue of Borelli's correspondence and to use his letters as a source of data suitable to map and chart Borelli's overlapping intellectual, social and political networks. ${ }^{4}$

The will (Fig. 1a-b) was drawn up on December 31, 1680 (that is 1679, according to the Nativity Style), the same day of Borelli's death. It was sealed in the General House of the Piarists fathers in San Pantaleo, not far from Piazza Navona, where Borelli had been living since September 1677. At that point the friars harbored him, due to his lacking adequate means after being robbed by a servant, in exchange for classes of mathematics for the seminarists. ${ }^{5}$ At

1 Acronyms: ASR: Archivio di Stato di Roma, Rome; BAV: Biblioteca Apostolica Vaticana; BML: Biblioteca Medicea Laurenziana, Florence; BNCF: Biblioteca Nazionale Centrale, Florence; DBI: Dizionario Biografico degli Italiani, 100 vols. (Roma: Istituto dell'Enciclopedia Italiana, 1960-2020). Biographical notes on Borelli in Ugo Baldini, "Borelli, Giovanni Alfonso," in DBI, XII (1971), s.v.; Thomas Settle, "Borelli, Giovanni Alfonso," in Dictionary of Scientific Biographies, II (New York: Charles Scribner's sons, 1970), s.v.; Antonino Scorsone, Giovanni Alfonso Borrelli: ricerche e considerazioni sulla vita e sulle opere (Palermo: Brotto, 1993); Stefania Montacutelli, "Giovanni Alfonso Borelli," in Il Contributo italiano alla storia del Pensiero. Scienze, ed. Antonio Clericuzio and Saverio Ricci (Roma: Istituto dell'Enciclopedia Italiana, 2013), 257-273; Luigi Ingaliso, "Borelli, Giovanni Alfonso," in Dizionario enciclopedico dei Pensatorie dei Teologi di Sicilia. Dalle origini al sec. XVIII, ed. Francesco Armetta (Caltanisetta-Roma: S. Sciascia, 2018), s.v.

2 Giovanni Giovannozzi, "Carte borelliane nell'Archivio generale delle Scuole Pie a Roma," Atti dell'Accademia pontificia de' Nuovi Lincei, A. 72, sess.e 3 (February 16, 1919): 81-86.

3 Archivio di Stato di Roma, Uffici della Curia del card. Vicario, Ufficio 32, vol. 257, cc. 476r-478v (notary Ludovico "Martolus"). On the Curia, see: Laurie Nussdorfer, Civic Politics in the Rome of Urban VIII (Princeton, N.J.: Princeton University Press, 1992), 50.

4 Borelli Galaxy (www.borgal.eu) results from a collaboration between the Department of History, Anthropology Religions Art and Performing Arts of Sapienza University of Rome, and the History Department of the University of Stanford, with the scientific supervision of Paula Findlen and Renata Ago. It has also benefited from the infrastructure, research support, and intellectual community of Stanford CESTA, Center for Spatial and Textual Analysis.

5 Giovannozzi, "Carte borelliane," 8n; Stefania Montacutelli, "Da Galileo a Borelli e oltre: la 

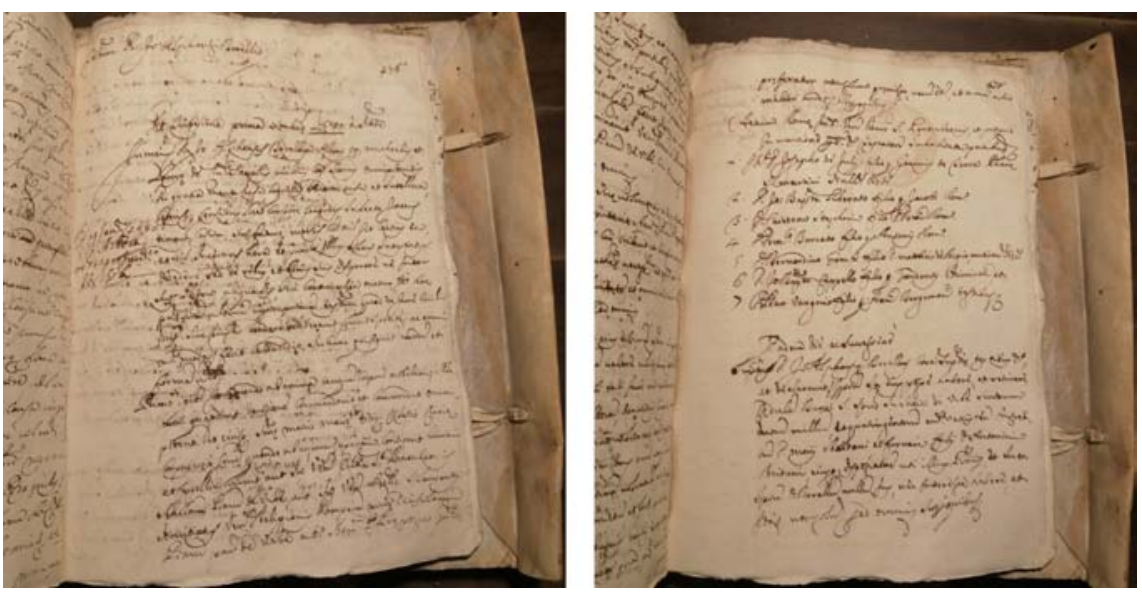

FIGURE 1A-B ASR, 30 Notai Capitolini, Uffici della Curia del card. Vicario, Ufficio 32, vol. 257 , c. 476r: Testamentum D. Jo: Alphonsi Borelli

that time, Borelli had been living in Rome for some years, having arrived there before June 1673 as a political exile. He had been banned from Messina in April 1672 by the Spanish governor of the city (the stratigoto) for being the alleged ideologue of a faction - the Setta-devoted to defending town privileges and opposing Spanish rule. ${ }^{6}$

This was not Borelli's first time in Rome. He had already spent the years of his training there, when, thanks to the informal teaching of Benedetto Castelli (who was then a lecturer of mathematics at Sapienza University), he converted to Galileo's natural philosophy and joined the "sect" of his followers. ${ }^{7}$ Between 1658 and 1659 he lived in the Urbs again for a few months, moving there from

filosofia naturale delle Scuole Pie a Roma nel Seicento," in Conflicting Duties: Science, Medicine and Religion in Rome, 1550-1750, ed. Maria Pia Donato and Jill Kraye (London-Turin:The Warburg Institute-Nino Aragno Editore, 2009), 192n.

6 Emile Laloy, La Révolte de Messine l'expedition de Sicile et la politique française en Italie, 16741678, I (Paris: Libraire C. Klincksieck, 1929), 82n, 151-152 and n.; Ugo Baldini, "Galileismo e politica: il caso borelliano," Annali dell'Istituto e Museo di Storia della Scienza 3, no. 1 (1978): 8193; Domenico Bertoloni Meli, "The Neoterics and Political Power in Spanish Italy: Giovanni Alfonso Borelli and His Circle," History of Science 34 (1996): 57-89.

7 The cultural scene of these years in Rome has been sketched by Maurizio Torrini: "Due galileiani a Roma: Raffaello Magiotti e Antonio Nardi," in La scuola galileiana. Prospettive di ricerca: Atti del Convegno di studio di Santa Margherita Ligure, 26-28 ottobre 1978 (Florence: La nuova Italia, 1979), 53-88. On Castelli's private academy of mathematics in Rome: Federica Favino, "Matematiche e matematici in Sapienza (XVII-XVIII sec.)," Mélanges de l'École Française de Rome 116, no. 2 (2004): 423-469, and Ead., "In urbe mathematicus: Torricelli a Roma," Galilaeana 6 (2009): 39-70. 
Pisa (where he was teaching mathematics at the University) to work on the Latin translation of the Arabic text of books 5-7 of the Conics of Apollonius of Perga, in collaboration with the Maronite Abraham Ecchellensis, a project sponsored by Borelli's patron, prince Leopoldo de' Medici. ${ }^{8}$ Like Borelli's first years in Rome, the period ${ }^{16} 63^{-1679}$ is also poorly documented: a few of his letters, some indirect testimonies and some academic lectures are all that remains. His last will now enriches this poor range of sources. This is a relevant document: not only and not so much because of the nature of the legacy, as will become clear, but because it portrays Borelli as settled at the very core of intertwined relationships of a different nature - intellectual affinities, social groupings, political loyalties, or even true factions - which shed new light on his last years, as well as on the publishing history of his last works.

This is not metaphoric imagery. In this paper, Borelli's will is used as a "sociotext," that is, as a "material evidence of social connectedness."9 The document is meant to be both an instrument used by Borelli to communicate and publicly display alliance, fidelity, and homage to his heirs and legatees and as a source for us to detect such social ties. The will is a freeze-frame of the relationships Borelli had, or wanted to exhibit, at the time of his death: a picture of his ego-network. By recording and analyzing — through the web infrastructure Nodegoat and the relational modes of visualization it provides ${ }^{10}$ - the inter-

8 Giovanni Giovannozzi, La versione borelliana dei Conici di Apollonio [...] con 21 lettere inedite di G.A. Borelli (Roma: s.n.t., 1916); Luigi Guerrini, "Matematica ed erudizione. Giovanni Alfonso Borelli e l'edizione fiorentina dei libri v, vi e viı delle Coniche di Apollonio di Perga," Nuncius 14 (1999): 505-564; Andrea del Centina and Alessandra Fiocca, "Borelli's Edition of Books V-VII of Apollonius's Conics and Lemma 12 in Newton's Principia," Archive for History of Exact Sciences 74 (2020): 255-279. On the maronite Abraam Ecchellensis: Bernard Heyberger, ed., Orientalisme, science et controverse:Abraham Ecchellensis (1605-1664) (Turnhout: Brepols, 2010).

9 I am borrowing the definition, mutatis mutandis, by Gary Schneider, The Culture of Epistolarity: Vernacular Letters and Letter Writing in Early Modern England, 1500-1700 (Newark: Univ. of Delaware Press, 2005), 27. On the will as historical source: 'Nolens intestatus decedere': il testamento come fonte della storia religiosa e sociale: Atti dell'incontro di studio, Perugia, 3 maggio 1983 (Perugia: Regione dell'Umbria: Editrice umbra cooperativa, 1985); Nigel Goose and Nesta Evans, "Wills as an Historical Source," in When Death Do Us Part: Understanding and Interpreting the Probate Records of Early-Modern England, ed. Tom Arkell, Nigel Goose, and Nesta Evans (Oxford: Leopard's Head Press, 20oo), 38-71. A use of the source comparable to the one I assume here, in: Elena Köstner, "Trimalchio's Last Will," Journal of Historical Network Research 3, no. 1 (2019): 1-29, https://doi.org/10 $.25517 /$ jhnr.v3i1.53.

10 BorGal currently runs on Nodegoat (https://nodegoat.net/), a web-based data management, network analysis and visualization environment developed by LAB11oo. BorGal datasets are organized around two main objects: "Letters" and "Persons," that we assume as 
actions between Borelli and his heirs and legatees, as well as the interactions that occurred outside this scope, I tried to reconstruct (and visualize) the social structure of this network, to single out Borelli's place within that complex system, and figure out its genesis." (Fig. 2) I assume here as a working hypothesis that taking a relational perspective, with the help of digital technology, might allow us to overcome the ideological approach to the subject of Borelli's political militancy and to test with facts the convergence of "Galileism" and politics by adopting, according to recent scholarship, the category of "faction" as an epistemological tool to understand early modern social and political dynamics. ${ }^{12}$ Last but not least, this data compared with the letters sent by Borelli in his last years in Rome, also offers a glimpse into his later editorial choices.

the main nodes of Borelli's network. Epistles provide evidence of the relationship between Borelli and each of his correspondents (nodes), but also on the other relationships they shared (further nodes), as well as on the quality and intensity of both. Letters are not our only source of information. In our view, other acts and circumstances contributed to build (and to disclose to scholars) relationships: for instance, co-editing or sponsoring a book, belonging to a group (Academy, learned circle, etc.), taking part in a public event. These elements are registered in BorGal as attributes or metadata of the nodes, providing pieces of contextual information that complete the network.

11 Visualization has been used here as a mode to bring an immediacy to perception of information and to facilitate the exploration of the multidimensional data sets generated in BorGal. No quantitative measures have been applied. From March 2022, users will be able to explore and view the BorGal datasets on the project website (www.borgal.eu/visuals/). An assessment on the many assumptions entailed in the uses of visualization by Network Analysis applied to the humanities, in: Ruth Ahnert, Sebastian E. Ahnert, Catherine Nicole Coleman, and Scott B. Weingart, The Network Turn: Changing Perspectives in the Humanities (Cambridge, UK-New York, NY: Cambridge University Press, 2020), with bibliography. A groundbreaking discussion on networks as a tool for historical research in Claire Lemercier, "Formal Network Methods in History: Why and How?", in Social Networks, Political Institutions, and Rural Societies, ed. Georg Fertig (Turnhout, Belgium: Brepols, 2015), 281-310 (https://halshs.archives-ouvertes.fr/halshs-oo521527v2). Further references on this fast-growing field of study at: https://historicalnetworkresearch.org $/ \mathrm{hnr}$ -bibliography-categories/.

12 To stick only to the places where Borelli carried out his political activity: Wolfgang Reinhard, Freunde und Kreaturen. "Verflechtung" als Konzept zur Erforschung historischer Führungsgruppen. Römische Oligarchie um 1600 (München: Vögel, 1979); Francesco Benigno, Specchi della rivoluzione (Roma: Donzelli, 1999); Id., "Lotta politica e sbocco rivoluzionario: riflessioni sul caso Messina (1674-1678)," Storica 5 (1999): 7-56; Gianvittorio Signorotto and Maria Antonietta Visceglia, eds., Court and Politics in Papal Rome, 1492-1700 (Cambridge, UK; New York: Cambridge University Press, 2002); Maria Antonietta Visceglia, "International Politics, Factions and Parties in the Roman Curia during the Late 16th Century," in A Europe of Courts, a Europe of Factions: Political Groups at Early Modern Centres of Power (1550_1700), ed. Rubén Gonzalez Cuerva and Alexander Koller (Leiden-Boston: Brill, 2017), $64-86$. 


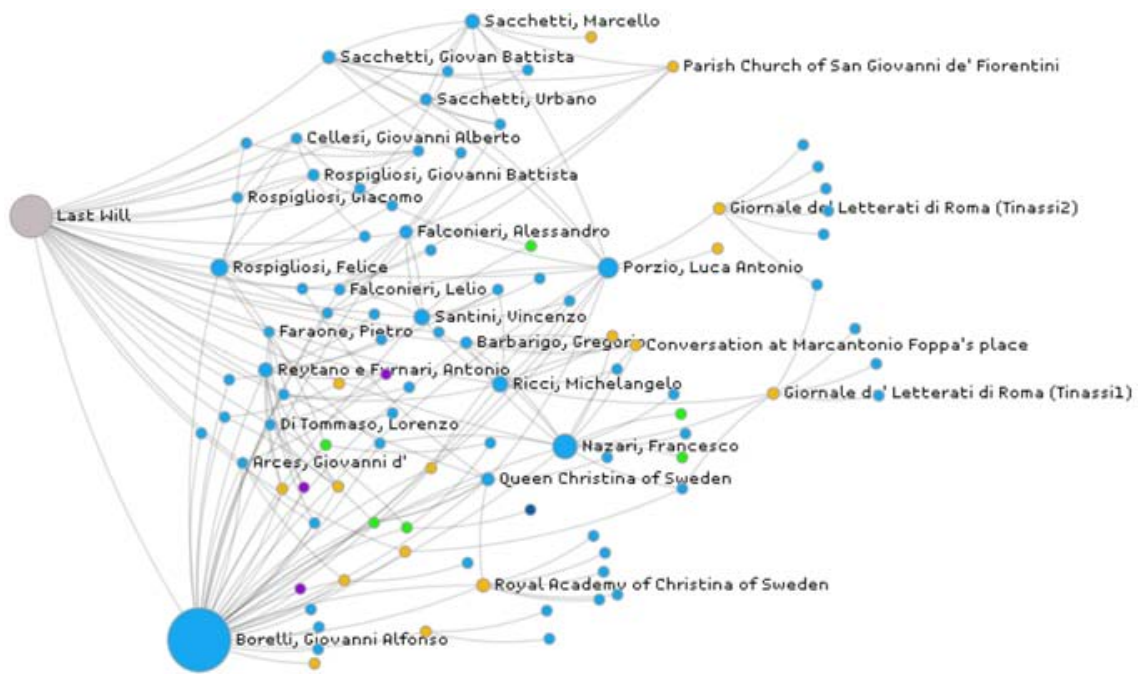

FIGURE 2 Visualization of Borelli's network on 31.12.1679, based on his will (see supra, note 10). Blue: person; green: book; yellow: group; purple: event. The size of the nodes is proportional to the number of their connections.

It is not surprising that, given Borelli's conditions at the time of his death, - an old unmarried layman, with no children and no assets - he appointed the General House of San Pantaleo as his sole heir. ${ }^{13}$ This was both a way to compensate the priests materially for supporting him in past years, and an act of gratitude towards his host, the Procurator General of the Order Carlo Giovanni Pirroni (1640-1685). ${ }^{14}$ Trained at the mathematical school of the "Galilean Piarists," Pirroni saw Borelli's recruitment as a move in a broader strategy to reform the educational offer of his Order, also in the field of natural philosophy. ${ }^{15}$ It is rather the allocation of bequests that draws Borelli's social network within late $17^{\text {th }}$ century Roman society.

13 This is the reason why Borelli's papers are kept in the Congregation's Archives at the General House of San Pantaleo (cf. above, note 5).

14 Leodegario Picanyol, Alfonso Borelli e il P. Carlo Giovanni Pirroni delle Scuole Pie (Romae: Curiam Generalitiam pp. Scolopi di S. Pantaleo, 1933).

15 Maurizio Sangalli, "Un Generale alle prese con la riorganizzazione delle Scuole Pie: Carlo Giovanni Pirroni e le sue prime quattro circolari 1677-1681," Archivum Scholarum Piarum 20, no. 39 (1996): 15-44; Federica Favino, "Scienza ed erudizione nei collegi degli ordini religiosi a Roma tra Sei e Settecento," Cheiron 43-44 (2005): 340-342; Montacutelli, "Da Galileo a Borelli e oltre," 181-205. 
Given his financial conditions, he does not bequeath his legatees money but his only asset: "complimentary" copies of his latest work, the De motu animalium, which at that time had not yet been printed, but had finally found a publication sponsor. ${ }^{16}$ Queen Christina of Sweden, who bestowed her patronage to Borelli after he had arrived in Rome from Messina and welcomed him to her Royal Academy, ${ }^{17}$ in late 1679 had eventually agreed to even bear the printing costs of the book: 100 doble, that is 300 roman scudi. ${ }^{18}$

The De motu plays a paramount role in this document. This book undoubtedly dominates the self-representation that the testator wanted to display in the face of the complex network he had woven around himself, in order to "the better to live and the better to survive death."19 If for Borelli, like for many of his contemporaries, a posthumous fame was the essential reward and ultimate fulfillment of an honorable and successful life, the De motu - where he constructed a science of the living body more geometrico demonstrata, open even to iatrochemistry ${ }^{20}$ — was the best way to achieve it. The book, already started when he was settled in Tuscany, was the crowning achievement of his long

16 The work was published in two volumes in 1680-1681, edited by Giovanni Carlo Pirroni, and was based on the original manuscript bequeathed by Borelli to the House of S. Pantaleo with his other papers: Giovanni Alfonso Borelli, De motu animalium ... opus posthumum (Romae, ex typographia Angeli Bernabò, 168o-1681). Borelli relied here on the copies that the author usually received from the printer as a form of payment upon delivery of the manuscript (Theodorus Bögels, Govert Basson: Printer, Bookseller, Publisher. Leiden 16121630 [Nieuwkoop: De Graaf Publishers, 1992], cap. 3). Such copies could become the object of a careful distribution management (Nicole C. Howard, Christiaan Huygens: The Construction of Texts and Audiences, Indiana University, ProQuest Dissertations Publishing, 2003).

17 Emanuele Zinato, "Ironia, parodia e dissimulazione nei Discorsi di Giovanni Alfonso Borelli," Filologia e Critica 25, nos. 2-3 (200o): 335-358; Maria Pia Donato, "Idiomi di straniere a Roma: Cristina di Svezia-Minerva e la sua accademia," in I linguaggi del potere nell'età barocca. Donne e sfera pubblica, ed. Francesca Cantù (Roma:Viella, 2011), 229-256; Claudia Tarallo, Discutere di poesia nella Roma tardo-barocca. I letterati dell'Accademia di Cristina di Svezia (Torino: Fondazione 1563 per l'arte e la cultura della Compagnia di San Paolo, 2017), passim.

18 The order for payment is registered in: ASR, Monte di Pietà, Depositi liberi, L. mastri, 350-351 (reported by Tomaso Montanari, "Bernini e Cristina di Svezia: alle origini della storiografia berniniana," in Alessandro Angelini, Gian Lorenzo Bernini e i Chigi tra Roma e Siena [Cinisello Balsamo: Silvana, 1998], 394), and in Archivum Generale Scholarum Piarum (Rome), Domus Generalitiae 116, Memoriae Domus S. Pantaleonis ab anno 1677, ad annum 1689 (reported in Montacutelli, "Da Galileo a Borelli e oltre," 195n).

19 Philippe Ariès, The Hour of our Death (New York: Knopf, 1981), 146.

20 Antonio Clericuzio, "The Other Side of the Accademia del Cimento," in The Accademia del Cimento and its European Context, ed. Marco Beretta, Antonio Clericuzio, and Lawrence M. Principe (Sagamore Beach: Science history publications, 2009), 19. 
research, as well as the completion of his plan to describe all the natural world according to geometrical and mechanical laws. More immediately, it was the accomplishment of his plan to compose a trilogy - after the release of the $O n$ the Force of Percussion (1667) and On the Natural Motions Resulting from Gravity (1670) - on terrestrial physics that encapsulated all of nature, from gravity to human and animal physiology. ${ }^{21}$

Borelli's self-identification with his masterpiece-alongside a complex set of patronage relations - for instance, also shines through the letter sent by Borelli from Rome to the astronomer Giovanni Domenico Cassini in Paris, on March 21, 1678. In this letter, confident to be soon elected to the Académie des Sciences by the King of France thanks to Cassini's recommendation, Borelli wrote:

[...] and since my old age of 70 prevents me from attending myself to serve His Majesty in his Academy, it is my duty to do so by sending this work of mine de motibus animalium (the result of many years of labor) to print it and to dedicate it to the most glorious name of His Majesty. ${ }^{22}$

Against this background, Borelli envisaged bequeathing to his patrons, fellows, and friends a book made up of his own flesh and blood.

The size of the legacy (that is the number of copies of the book) does not seem to reflect the strength of Borelli's own relationships (its edge weight to use a

21 Luciano Boschiero, "Introduction," in Borelli's On the Movement of Animals—On the Force of Percussion, trans. Paul Maquet (Cham: Springer, 2015), XI-XII. On Borelli's approach to "physico-mathematics," see also Domenico Bartoloni Meli, Thinking with Objects: The Transformation of Mechanics in the Seventeenth Century (Baltimore: Johns Hopkins University Press, 2006), passim; Stefania Montacutelli, "Air "Particulae" and Mechanical Motions: From the Experiments of the Cimento to the Hypotheses on the Nature of Air by Borelli," in The Accademia del Cimento, 59-73.

22 "[...] e poi che la mia grave età settuagenaria non permette che io possa venir di presenza a servire S.M. nella sua accademia, è dovere che io lo facci con mandar questa mia opera de motibus animalium (travaglio di molt'anni) per stamparla e dedicarla al gloriosissimo nome di S.M." (Tullio Derenzini, "Alcune lettere di Giovann Alfonso Borelli a Gian Domenico Cassini," Physis 2, no. 3 [1960]: 237). The 4 letters sent from Borelli to Cassini between November 20, 1676, and May 17, 1678-edited by Derenzini-clearly show that the astronomer took steps to have Borelli elected as a salaried member of the Académie Royale des Sciences, of which he had been a member since 1669. This would have given 
Social Network Analysis terminology). Of course, he assigns to Her Majesty Queen Christina all the copies that she might want, so that she will distribute them among European learned men, firstly among the members of her Royal Academy. His pupil Vincenzo Santini, the Florentine mathematician who is mentioned in the will as the tutor of the young sons of Duke Francesco Paolo Falconieri, is also an exception..$^{23}$ Borelli bequeathed to him two copies of the book, as well as a quadrant and a telescope. Two copies of the book are also reserved for the young Falconieri brothers, Lelio and Alessandro, Borelli's own pupils at the time, perhaps as an exhortation to continue studying mathematics and certainly as an act of gratitude. ${ }^{24}$ Only a few months before, in 1679, Alessandro had paid for the printing costs of the second edition of Borelli's

Borelli the ease of finishing the De motu and a sponsor to publish it. The project, to be carried out thanks to the mediation of Minister Colbert and Cardinal César d'Estrée, eventually failed.

23 A gentleman from Florence, Santini (c. 1652-c. 1722) had learnt geometry in his hometown by the Piarist mathematician Famiano Michelini. He enjoyed the protection of Cardinal Leopoldo de' Medici, who sent him to attend the Roman Seminary to assure him a position as a priest and supported him financially. After Leopoldo's death, on November 10, 1675, Santini, who was about to leave the Seminary (which happened in 1677), begged for financial aid from the Grand Duke of Tuscany through the intercession of Vincenzo Viviani. In 1680 he eventually gained a position in the Curia as a secretary of "a Cardinal"-most likely Girolamo Casanate (1620-1700) — and gave up his mathematical studies for a while. His correspondence with Viviani from 1670 to 1682 (cfr. Florence, Biblioteca Nazionale Centrale, Ms. Gal. 164, c. 156r; Gal. 165, 49r-v, 57v-58v, 6or-61r, 63r, 188r, 19or; Gal. 166, cc. $\left.3^{r-v}, 103^{r-104 r}, 120 r-v, 141 \mathrm{r}-\mathrm{v}\right)$ is the richest source of biographical information on him. The only other biographical source for Santini is the "Avviso al lettore" by the printer Giovanni Domenico Capurri, in Vincenzo Santini, Delle sezioni coniche dedotte nuovamente in piano dal Cerchio, date per saggio dell'altre che dal medesimo deduconsi (Lucca, 1722), republished by Giovanni Targioni Tozzetti and Pietro Riccardi (respectively: Attie memorie inedite dell'Accademia del Cimento e notizie aneddote dei progressi delle scienze in Toscana ... [In Firenze, si vende da Giuseppe Tofani stampatore e da Luigi Carlieri librajo, 1780], I, 224; Biblioteca matematica italiana [Modena: Tipografia dell'erede Soliani, I/II, 18731876], 420). According to Capurri, who confirms the bonding between Santini and Borelli, in 1700 the priest retired in Salisano, near the Abbey of Farfa, for health reasons, where he wrote the book on the Conics that he dedicated to his former pupil Alessandro Falconieri.

24 They were both born to Vittoria del Bufalo (1594-) and Paolo Francesco Falconieri (16261696), the cousin of Paolo Falconieri (1634-1704), the good friend of Lorenzo Magalotti who acted in Rome as an agent for Leopoldo de' Medici (Mario Bencivenni, DBI, 44 [1994]). The young Lelio Falconieri $\left(1655^{-1717}\right)$ would succeed his father in the administration of the family assets (Maria Barbara Guerrieri Borsoi, Villa Rufina Falconieri: la rinascita di Frascati e la più antica dimora tuscolana [Roma: Gangemi, 2008], 44-46), while his younger brother Alessandro (1657-1734) would become cardinal in 1727 after a long career in the Roman Curia (Matteo Sanfilippo, "Falconieri, Alessandro," in DBI, 44 [1994], s.v.). 
Euclides restitutus. ${ }^{25}$ Alessandro himself signed the dedication of the volume to his former fellows at the Jesuit College in Parma and mentioned Borelli as "praeceptor meus ... in mathematicis disciplinis." 26

Except for these cases, the inheritance left by Borelli is the same for everyone-one copy of the De motu - and the legatees are haphazardly named, seemingly written in whatever order came to the mind of the testator. And yet, digital network research allows us to cluster these apparently scattered people, to visualize their reciprocal links and to figure out the nature and origin of their relationships with Borelli.

Lorenzo di Tommaso and Lucantonio Porzio are the only two who received money instead of the book. In their case, money is meant as the payment for their professional services as medical doctors. Of course, both meant much more than this in Borelli's life. He had been in contact with Porzio since 1667, when they had met in Naples at the Accademia degli investiganti. ${ }^{27}$ From 1670, when Porzio moved to Rome from Naples, looking for better career opportunities and for an environment conducive to its innovative ideas, as Maurizio Torrini states: "Porzio became Borelli's faithful spokesman in the Roman environment and an agent at his commands." ${ }^{28}$ When it was Borelli's turn to come to the Urbs, Porzio probably was among those friends who facilitated his contacts with Queen Christina, whose patronage Porzio also enjoyed. ${ }^{29}$ Looking at the visualization, it is apparent that Porzio is also the broker between

25 Euclides restitutus denuò limatus, siue Prisca geometriae elementa breuiùs, \& faciliùs contexta. In quibus praecipuè proportionum theoriae noua firmiorique methodo proponuntur ... A Io. Alphonso Borello (Romae: ex typographia Mascardi, 1679).

26 "Illustrissimis dominis parmensis collegii Convictoribus Alexander Falconerius felicitatem," ibid., 2-3.

27 On Borelli's stay in Naples in 1667 , see V.M.H. Fisch, "The Academy of the Investigators," in Science Medicine and History: Essays on the Evolution of Scientific Thought and Medical Practice Written in Honour of Charles Singer, ed. Edgar Ashworth Underwood (Oxford: Oxford University Press, 1953), I, 536-537, and Paolo Galluzzi, "G.A. Borelli dal Cimento agli Investiganti," in Galileo e Napoli, ed. Fabrizio Lomonaco and Maurizio Torrini (Naples: Guida, 1987), 339-355.

28 Maurizio Torrini, Dopo Galileo: una polemica scientifica, 1684-17n (Florence: L.S. Olschki, 1979), 171. On Porzio, see also: Alessandro Dini, Filosofia della natura, medicina, religione: Lucantonio Porzio (1639-1724) (Milan: F. Angeli, 1985).

29 Porzio was not in perfect harmony with the Queen, whose high self-esteem, and pseudoscientific interests he did not approve of (Giuseppe Mosca, Vita di Lucantonio Porzio pubblico primario cattedratico di notomia, prima nella Sapienza di Roma, e poi nello Studio di Napoli, e Conte Palatino. Scritta da Gioseppe Mosca napoletano dottor di filosofia, e medicina. Con alquante lettere di alcuni letterati al Porzio indirizzate, e con una del medesimo, Del maggior traffico chè nel mondo, ora per la prima volta stampata [Naples: presso Gennaro Migliaccio, 1765], 30). 
Borelli and what a network research reveals to be a cluster of actors- the Sacchetti brothers, the Marquis Theodoli, the Duke Filippo Nerli—who were tied by matrimonial bonds (the women of the Sacchetti family, who are sisters of the formers and wives of the latters). ${ }^{30}$ This visualization's results fit perfectly with the biographies of Porzio. According to Porzio's 18th century biographer Giuseppe Mosca, the families we just mentioned had welcomed Lucantonio and patronized him since his arrival in Rome. ${ }^{31}$ Marquis Filippo Nerli, for instance, is said to have sponsored Porzio's chair of Medicine at Sapienza University in $1671 .^{32}$ The clan included at least one cardinal, Francesco Nerli, the admirer of Pythagoras, whose life Porzio planned to write, ${ }^{33}$ while the Marquis Theodoli was among the noblemen who urged Cardinal Flavio Chigi to gather together a New Experimental Physico-mathematical Academy, on the model of the Academy of the Cimento, that was attended by Porzio and informally even by Borelli. ${ }^{34}$ It is most likely that Porzio also shared these relationships of

30 In the will, they are referred to as: "Sig.r Marchese Theodoli, Marchese Nerli, Marchese Sacchetti, monsig.r Sacchetti, Sig.r Cavalier Sacchetti.” The Sacchetti brothers are respectively to be identified as follows: Marquis Giovanni Battista (1639-1688), head of the household; 'monsegneur' Urbano (1640-1705), clerks of the Apostolic Chamber at the time and Marcello (1644-1720), knight of justice at the Order of Malta (Irene Fosi, Allombra dei Barberini:fedeltà e servizio nella Roma barocca [Rome: Bulzoni, 1997], passim; Lilian H. Zirpolo, Ave Papa ave papabile: The Sacchetti Family, their Art Patronage, and Political Aspirations [Toronto: Centre for reformation and renaissance studies, 2005], $126 \mathrm{ff}$.). Two of their sisters: Maria Francesca (1641-1714) and Ottavia (1647-1679), had respectively married Carlo Maria Theodoli (1633-1697), Marquis of San Vito and Pisoniano and Filippo Nerli (1639-1712), Marquis of Resina. It is worth mentioning that also Paolo Francesco Falconieri, as a son of one of Cardinal Giulio's sisters, Ottavia Sacchetti (15901645), was in all respects a member of the clan. When Galileo arrived in Rome in 1610 he had been welcomed by a comparable "clan" of families linked to the Farnese household through the same social dynamics (Federica Favino, "Le ragioni del patronage: i Farnese di Roma e Galileo," in Il caso Galileo: una rilettura storica, filosofica, teologica: convegno internazionale di studi, ed. Massimo Bucciantini, Michele Camerota, and Franco Giudice [Florence: L.S. Olschki, 2011], 163-185).

31 According to Mosca (Vita, 72), Nerli was the first of Porzio's patrons in Rome. As to Theodoli, a letter sent by him to Porzio in 1683 (ibid., 103-105) testifies to the protection granted by the marquis to the doctor and to their familiarity. On Cardinal Francesco Nerli senior (1595-1680), see Stefano Tabacchi, "Nerli, Francesco," in DBI, 78 (2013), s.v.

32 Mosca, Vita, 73. Porzio held the extra-chair of Medicine in Sapienza from 1671 to 1683 , but in 1681 in fact he stopped teaching there (Torrini, Dopo Galileo, 170-171, 181).

33 Mosca, Vita, 72.

34 The role of Theodoli in the initiative, as well as Borelli's presumed belonging to it, was told by the Jesuit mathematician Antonio Baldigiani to Francesco Redi in a letter from Rome dated 1674 (вмL, Redi, ms. Redi 219, f. 138, quoted in Maria Pia Donato, "Late Seventeenth-Century Scientific Academies in Rome and the Cimento's Disputed Legacy," 
patronage with his friend Borelli, and that the latter was pleased to leave them a memory of himself as a sign of gratitude.

\section{$4 \quad$ Cluster 2: Party Comrades}

Lorenzo di Tommaso was also much more than just medical doctor to Borelli. In Messina, where he worked as an apothecary, Lorenzo was a good friend to Borelli and Marcello Malpighi, when in 1662 the latter had been appointed to the chair of Medicine at the local University through Borelli's mediation. ${ }^{35}$ At the time of his ban in 1672 , Borelli and di Tommaso were working together on editing Francesco Maurolico's version of Archimedes based on the manuscripts donated to the apothecary by Maurolico's heirs in exchange for his medical services. This work, financed by the Messina city Council, was almost completely printed when it had to be abandoned in the aftermath of Borelli's escape. ${ }^{36}$

in The Accademia del Cimento, 16on). As Maurizio Torrini has already pointed out, Theodoli "must have been an important figure in the Roman cultural scene" (Dopo Galileo, 68n). In 169o, he was the sponsor and the dedicatee of the Lettere Famigliari by Lorenzo Magalotti, a collection that he had known and praised in Rome thanks to Paolo Falconieri (Al Signor Marchese Carlo Theodoli mio signore, ibid., V-XI). Porzio recalls his experiments with the Torricellian tubes at Cardinal Chigi's home in Opera omnia (Naples: typis Felici Caroli Mosca, expensis Cajetani Elia, 1736), 280-281. On Antonio Baldigiani S.J. (16471711), see: Paula Findlen, "Living in the Shadow of Galileo. Antonio Baldigiani (1647-1711), a Jesuit Scientist in Late Seventeenth Century Rome," in Conflicting Duties, 211-254.

35 Biographical notes on di Tommaso extracted from Malpighi's letters and works, in Howard B. Adelmann, ed., The Correspondence of Marcello Malpighi (Ithaca: Cornell university press, 1975), II, 469 e n., letter n. 227 and ad indicem. Exiled in Rome in 1679, he worked there as a doctor until his death, probably in April 1684 (BML, Redi, Redi 216, ff. 177 r-v, $366 \mathrm{r}-367 \mathrm{v}$ ). His son Giovanni was on good terms both with Francesco Redi (ibid., Redi 214), and Malpighi (The Correspondence, ad indicem).

36 Archimedis monumenta omnia Mathematica ... ex traditione Maurolyci, for the Messinese printer Bonacota, with dedication to the Senate of Messina. The work, remained unfinished in 1672 , was published in 1685 by Juan Silvestre Salva (Admirandi Archimedis Syracusani Monumenta omnia mathematica, quae extant, quorumque catalogum inuersa pagina demonstrat, ex traditione ... d. Francisci Maurolici ... opus praeclarissimum, non priùs typis commissum [Panormi: apud d. Cyllenium Hesperium sub signo Aureae Conchae: sumptibus Antonini Giardinae bibliopolae Panormitani, 1685]). On this episode, see: Rosario Moscheo, "Scienza e cultura a Messina fra ‘ 500 e ‘6oo. Vicende e dispersione finale dei manoscritti autografi di Francesco Maurolico (1499-1575)," Archivio Storico Messinese, s. 3, 28 (1977): 5-83, and Id., "Il Corpus mauroliciano negli 'Sphaerica' problemi editoriali," in Filosofia e Scienze nella Sicilia dei Secoli XVI e XVII, ed. Corrado Dollo (Palermo: Regione siciliana, Ass. ai bb. cc. aa. e p. i.; Catania: Università, Dipartimento di scienze storiche, Centro di studi per la storia della filosofia in Sicilia, 1996), 39-86. 
The BorGal relational database highlights and discloses Lorenzo's ties with other Borelli's legatees who participated in the Revolt of Messina against the Spanish rule of 1674-1676-Antonio Reytano e Furnari, Giovanni d'Arces, Pietro Faraone - who were all members of the noble families who dominated the city Council of Messina and led the Malvizzi party until the defeat of the revolt. ${ }^{37}$ The letters from Borelli's correspondence complete the picture: Reytano-whom Borelli called "amico svisceratissimo"38_ had been one of Malpighi's noble patrons in Messina; ${ }^{39}$ while d'Arces in turn was a close friend of Borelli's last patron in Sicily, Giacomo Ruffo, Viscount of Francavilla. ${ }^{40}$ Like Borelli, he had been a member of the Accademia della Fucina, a breedingground of political dissent against the Spanish government in late 17th century Messina ${ }^{41}$ Pietro Faraone had been among the leaders of the "Setta," ${ }^{42}$ the radicalized faction whose members were anti-Jesuits, republicans, and pro-

37 The bibliography on the Revolt of Messina is extensive. Recent references include: Benigno, Lotta politica e sbocco rivoluzionario; Saverio Di Bella, Caino Barocco. Rivoluzione, Colpo di Stato, Repressione, Messina 1672-1678 (Cosenza: Pellegrini, 2002); Salvatore Bottari, "Post res perditas": Messina 1678-1713 (Messina: A. Sfameni, 2005); Luis Antonio Ribot García, La rivolta antispagnola di Messina. Cause e antecedenti (1591-1674) (ed. or. 1982; Soveria Mannelli: Rubbettino, 2011). See also: Daniela Novarese, " "Hanno andato machinando, facendo unione, seducendo i popoli al disservizio ed in danno di Sua Maestà": 1674-1678: note sullo Studium Messanae negli anni della rivolta antispagnola," in Università e formazione dei ceti dirigenti: per Gian Paolo Brizzi, pellegrino dei saperi, ed. Giancarlo Angelozzi, Maria Teresa Guerrini, and Giuseppe Olmi (Bologna: Bononia University Press, 2015), 279-298.

38 G.A. Borelli to M. Malpighi, Firenze, August 18, 1663, in The Correspondence, I, 181.

39 In 1648 Antonio Reytano e Furnari gained the title of Baron of S. Pietro (fief purchased in 1646) by the King of Spain Philip IV, and was awarded the Malta Cross (Della Sicilia nobile, 126). He owned a Villa in Torre Faro (not far from Messina) and was widowed in summer 1663. He was elected as a representative of the Messinese aristocracy to the City Council in 1672, 1676, 1678 and was a leader of the Malvizzi (Laloy, La Révolte, ad indicem). Borelli advised Malpighi to ask for his help in obtaining specimens of fish to be dissected (The Correspondence, I, ad indicem).

40 Giovanni d'Arces is among the friends that Giacomo Ruffo recalled in his last will (drafted on September 2, 1674), along with Antonio Reytano and Giovanni Alfonso Borelli (Maria Concetta Calabrese, I Ruffo a Francavilla: la corte di Giacomo nel Seicento [Messina: A. Siciliano, 2001], 46n).

41 Giacomo Nigido-Dionisi, L'Accademia della Fucina di Messina (1639-1678) ne'suoi rapporti con la storia della cultura in Sicilia (Catania: Giannotta, 1903); Attilio Russo, "L'Accademia della Fucina di Messina: una società segreta esistente già dal primo decennio del secolo XVII," Archivio Storico Messinese 73 (1997):139-172; Salvatore Bottari, "The Accademia della Fucina: Culture and Politics in Seventeenth-Century Messina," in The Italian Academies 1525-1700: Networks of Culture, Innovation and Dissent, ed. Jane E. Everson, Denis Reidy, and Lisa Sampson (London: Routledge, 2016), 77-86.

42 Laloy, La Révolte, I, 83. According to the stratigoto De Hojo, even Antonio Reytano was connected to the "Setta." 
French.$^{43}$ Like Borelli, whom the Spanish captain-general Louis de Hojo judged to be the ideologue of this faction, Faraone was banned from the city in April $1672,{ }^{44}$ but unlike Borelli, he and his party comrades had remained in their hometown and had actively participated in the armed revolt. ${ }^{45}$ In different but equally dramatic ways, by 1679 they had all settled in Rome as-political-exiles, relying on the few assets brought with them when they fled Messina. ${ }^{46}$ In Fall 1679 the painter and naturalist Agostino Scilla also joined the group, just in time to pay homage to his friend Borelli with the small portrait placed on top of his funerary slab in the Church of San Pantaleo (Fig. 3a-b). ${ }^{47}$

Among the expats listed in Borelli's will there was also Mario Reytano, Antonio's son, who was also compromised by the revolt. ${ }^{48}$ The note that appears at the end of the document speaks of a particular confidential relationship between the two. It seems the note was apparently added later, after the document had already been signed, even after the list of witnesses. It states that the same day, Borelli suddenly remembered that "perhaps" among his papers there was a 2400 scudi coupon issued by the public bank of the Hospital Santo Spirito in Sassia, that was registered to Mario Reytano and was held by Borelli who had

43 Benigno, Lotta politica e sbocco rivoluzionario, 211.

44 Giuseppe Arenaprimo, "Gli esuli messinesi del 1678-1679: notizie e documenti," Archivio Storico Messinese 5, nos. 3-4 (1904): 70-137.

45 Faraone had been a member of Messina city Council in 1659, 1662, 1665 (Saverio Di Bella, Caino Barocco. Messina e la Spagna, 1672-1678: con documenti inediti e rari [Cosenza: Pellegrini, 2005], 112-114). He was among the leaders of the Revolt, after the revolutionary rupture. A staunch republican (Laloy, La Révolte, I, 453), as a senator belonging to the anti-government party of the Malvizzi, in October 1674 he led the Messinese troops to assault the castle of San Salvatore garrisoned by the Spaniards (ibid, I, 143-151 and ad indicem).

46 Antonio Reytano e Furnari, Pietro Faraone and Giovanni d'Arces left Messina on the ships of the French Army evacuating Sicily (March 16, 1678), and heading towards Marseille and Toulon (Arenaprimo, Gli esuli, 125, 128, 132). Reytano was singled out by the rebels to go to Paris, to ask Louis XIV to protect the Messina exiles in the peace negotiations with Spain. He was expelled from Paris with his son in February 1679 , after the exiles had already been driven out of Provence, in Autumn 1678 (Laloy, La Révolte, III, 765).

47 Luigi Hyerace, "Ancora su Agostino Scilla," Prospettiva, nos. 126-127 (2007): 156-168, and Id., "Scilla, Agostino," in DBI, 91 (2018). For his contribute to the study of the natural world of fossils and animals: Paula Findlen, "Agostino Scilla: A Baroque Painter in Pursuit of Science," in Science in the Age of Baroque, ed. Ofer Gal and Raz Chen-Morris (Dordrecht: Springer, 2013), 119-159; Domenico Laurenza, "The Study of Fossils in Leonardo, Scilla and Hooke," in "Visual Representation in Earth Sciences History after 'The Emergence," ed. Luca Ciancio and Domenico Laurenza, special issue, Nuncius 33, no. 3 (2018): 442-463.

48 To be sure, he took part in the assault of the San Salvatore fortress, in October 1674 (Laloy, La Révolte, III, 765). 


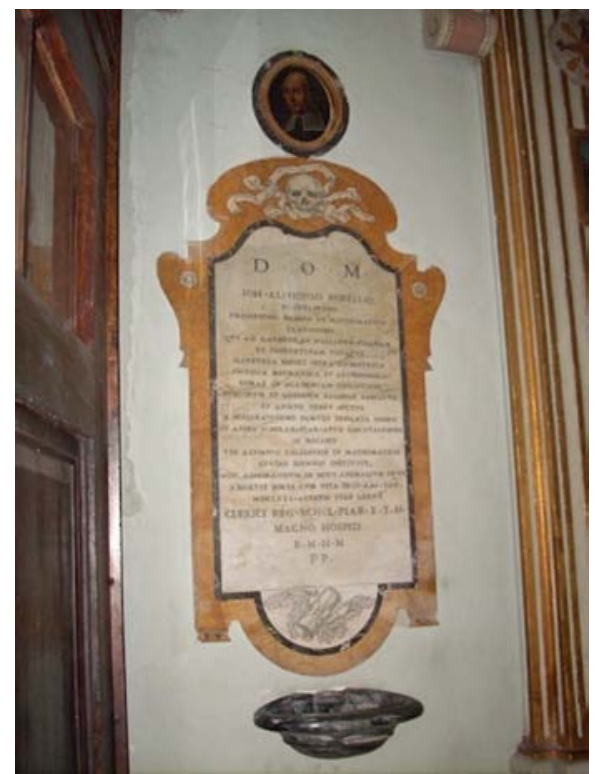

FIGURE 3A

Giovanni Alfonso Borelli's funereal monument, San Pantaleo Church, Rome

PHOTO BY LUCA BORGHI (HTTP://HIMETOP .WIKIDOT.COM/)

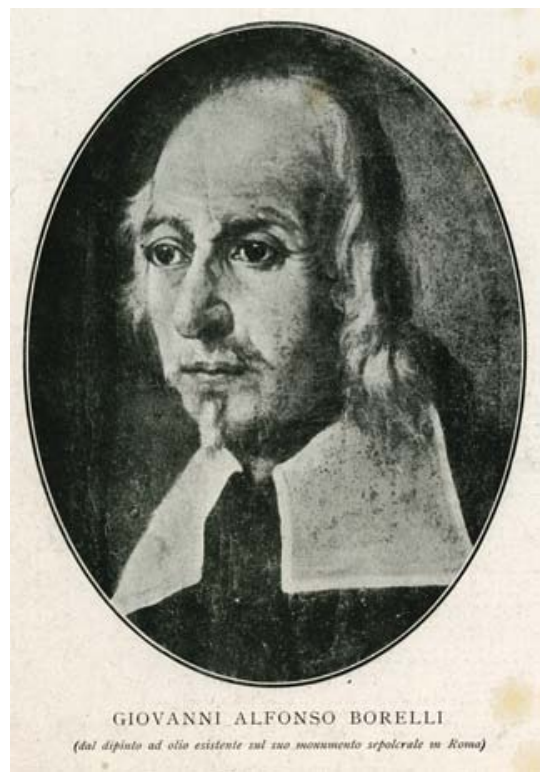

FIGURE 3B

Agostino Scilla, Portrait of Giovanni Alfonso Borelli, from a painting in oils on his tomb in Rome

PHOTO: COURTESY OF MUSEO GALILEO, FLORENCE

no interest in it, acting only as Reytano's legal representative. ${ }^{49}$ According to a document drawn up after Borelli's death, the mathematician had in fact managed Reytano's bank account on his behalf since May 1679 (that is likely the date ante quem the Reytanos took refuge in Rome), which held all the capital the family had got to safety. ${ }^{50}$

49 See infra, Testamentum, p. 173. On the Bank of Santo Spirito launched in 16o6: Ermanno Ponti, Il Banco di Santo Spirito e la sua funzione economica in Roma Papale (1605-1870) (Rome: Officina Poligrafica Laziale, 1951), and Luigi De Matteo, Un banco pubblico nello Stato Pontificio. Il banco di Santo Spirito dalle origini al 196o (Rome: Banca di Roma, 2001). Consignatio Cedulae pro Venerabili Dopo Sancti Pantelonis, in ASR, Uffici della curia del card. Vicario, Ufficio 32 , vol. 257 , f. 18 or-v. The sum of 2500 shields was all but negligible. It was equivalent to more than 8 times the money paid by Christina for the publication of the $D e$ motu. With a lesser sum, at the time in Rome you could purchase a permanent position as a papal guard (Roberta Masin, Il debito pubblico pontificio a fine Seicento: i monti camerali [Città di Castello: Edimond, 2005], 117). 


\section{Cluster 3: Factions' Members}

It is not news that, once in Rome (from March 1673), Borelli had been an agent on behalf of the rebels in Messina and that he had intense contacts with the French Embassy in Rome, which at the time was run by the intriguing d'Estrées brothers, the Duke Annibal Francois II and the powerful Cardinal César. ${ }^{51}$ Some clues suggest that Borelli, when the rebels asked for the alliance of the King of France, provided d'Estrées — who called him "grand mathématicien et si bon Français" — with plans for military machines and strategic information on the Messina territory and society. ${ }^{52}$ In late summer 1674 , on his turn, d'Estrées had acted as the intermediary between the "flying ambassadors" sent by the Sicilian rebels and Louis XIV to ask for his help and protection. One of them was the same apothecary di Tommaso who was present at Borelli's deathbed. ${ }^{53}$ Sent to Paris again in October 1675 , to obtain the promise from the King, to provide

$5^{1} \quad$ Annibal Francois II d'Estrées (1623-1687), was extraordinary ambassador on behalf of the King of France from 1670 to 1687 . His brother César (1628-1714), Duke-Bishop of Laon (1653) was elected cardinal by Pope Clement X in 1671. He participated in four conclaves and contributed to the election of Clement XI. He dealt with French interests in the Curia and made his influence felt in the condemnation of quietism (Lorenzo Cardella, Memorie storiche de' cardinali della santa romana Chiesa scritte da Lorenzo Cardella parroco de'ss. Vincenzo, ed Anastasio alla Regola in Roma [Rome: nella stamperia Pagliarini, 1793], VII, 208; R. Darricau, "Estrées (César d')," in Dictionnaire de biographie française, vol. 13 [Paris: Librairie Letouzey et Ané, 1975], 144-147). On the diplomatic relations between France and the Holy See, cf. S. de Dainville-Barbiche, ed., Correspondance du nonce en France Fabrizio Spada (1674-1675) (Rome: Ecole Francaise de Rome, Universite Pontificale Gregorienne, 1982), 23-76, and Jean Orcibal, Louis XIV contre Innocent XI. Les appels au futur Concile de 1688 et l'opinion française (Paris: Vrin, 1949).

52 In October 1674 , for instance, waiting for the French to be sent to Sicily to support Messina in revolt, Borelli offered to make Cardinal d'Estrées a device of his own invention (the nature of which is unknown) at the disposal of the anti-Spanish party (Laloy, La Révolte, I, 445-446, but see also 368). In June 1675 he made the offer again (ibid., II, 166). In 1676, he unintentionally caused the Spanish Ambassador Cardinal Nithard to find out the plot woven in Palermo by the Prince of Valdina and by several members of the Ventimiglia family (ibid., II, 638-650). On the diplomatic activity of the French and Spanish ambassadors in Rome with regard to the events happening in Messina, see: Ribot Garcia, $L a$ Monarquía de España, 530-570, and Laura Oliván Santaliestra, "Nithard en Roma: orgullo y ambiciones (1672-1677)," in I rapporti tra Roma e Madrid nei secoli XVI e XVII: arte, diplomazia e politica, ed. Alessandra Anselmi (Roma: Gangemi editore, 2015), 549-570.

53 Laloy, La Révolte, I, 284, 429-432, 443; II, 201, 203, 216, 289, 355, 362. Di Tommasowho was a member of the Messina city Council deputed by the bourgeoisie-left Sicily with Antonino Caffaro, son of the prince and senator Tommaso. They reached Tolouse via Rome, with the help of d'Estrées. Eventually, the mission (August-September 1674) obtained the dispatch of the small convoy of French ships, led by the knight Jean-Baptiste de Valbelle. 
Sicily with a proper king once the Spaniards had been driven away, ${ }^{54}$ di Tommaso took the opportunity to inform Cassini of the difficulties that Borelli was facing in exile, so much so that Cassini resolved to intercede with the King in favor of Borelli's appointment to the Académie des Sciences. ${ }^{55}$ In the meantime, Cardinal d'Estrées, who had been a member of the Académie since 1656 , was doing the same with the prime minister Jean Baptiste Colbert. ${ }^{56}$ We don't know why the negotiation eventually failed, after Borelli-still in May 1678 had already decided to dedicate the new edition of the Conics bound together with Archimedes' works to Colbert and to title himself on its frontispiece as "Royal academician." ${ }^{57}$ In any case, at that point it had been probably easy for

54 Ibid., II, 288-289.

55 See letter from G.A. Borelli to Giovanni Domenico Cassini, Rome, November 20, 1676: "Doppiamente son tenuto ringraziare vs. Ill. ${ }^{\mathrm{ma}}$, sì per la disposizione che aveva di far che io conseguissi la dignità d'esser ammesso nella famosa accademia del Re Christianiss.o mio supremo Signore, sì anco per aver prevenute le mie preghiere, conforme mi ha significato da Messina il Sig. ${ }^{r}$ Lorenzo di Tomaso. So che dalla voce viva del medesimo Ella ha saputo lo stato nel quale mi ha ridotto la barbarie de' gli nimici, eperò non istarò a narrarli come le strettezze e l'inquietudini d'animo che ho patito non mi anno lasciato finire né questa tanto travagliata opera de movimenti mechanici degli animali, né altre che mi trovo imperfette ..." [I am doubly obliged to thank Your Most Illustrious Lordship, both for the will you had to ensure that I obtain the dignity of being admitted to the famous Academy of the Most Christian King, my supreme Lord, and for having prevented my prayers, according to what Mr. Lorenzo di Tomaso made me understand from Messina. I know that from the living voice of the same, You learned the state in which the barbarism of the enemies has reduced me, and yet I will not bother to tell You how the strains and the anxieties of soul that I have suffered prevented me from completing neither this much troubled work on mechanical movements of animals, nor other imperfect works that I have with me ...] (Derenzini, Alcune lettere, 237-238).

$5^{6}$ According to the survived Borelli-Cassini correspondence published by Derenzini (November 20, 1676-May 17, 1678), Cardinal d'Estrées interceded (or planned to intercede) with Colbert through the Abbot Jean Gallois, the co-founder of the Journal des sçavans who at the time was very close to the Minister (Bernard de Fontenelle, "Eloge de Jean Gallois," in CEuvres, nouv. éd. augmentée [Paris, au Palais: chez Michel Brunet, pere, au Mercure Galant, 1742], v, 179). As a patron of the sciences, d'Estrées is remembered above all for having commissioned the two large globes now exhibited in the National Library of Paris from Pietro Coronelli, as a gift for King Louis XIV (Monique Pelletier, "Les Globes de Louis XIV: les Sources françaises de l' oeuvre de Coronelli," Imago Mundi 34 [1982]: 72-89, and Ead., "La famille d'Estrées et les globes de Coronelli," in Les globes de Louis XIV: étude artistique, historique et matérielle [Paris: Bibliothèque nationale de France, 2012], 16-33).

See the letter sent from Borelli to Giovanni Domenico Cassini, from Rome, on May 17, 1678, in Derenzini, Alcune lettere, 240-241. On that date Borelli-assured by Cassini that his enrolment was certain—still meant to have a second copy of the whole De motu drawn up and sent to Paris to be submitted to the Académie des Sciences. In the same letter he still planned to publish the third edition of the Euclides restitutus - that was later spon- 
d'Estrées brothers to provide Borelli in Rome with another dedicatee for the book, Cardinal Felice Rospigliosi (1639-1688), who-like his own elder brother Giacomo (1628-1684), also one of Borelli's legatees—had excellent relations with the King of France. ${ }^{58}$ Network historical research can help us put into relation all this data and, consequently, understand why so many members of the Rospigliosi clan appear within Borelli's network: cardinals, relatives, servants. ${ }^{59}$ Like the families of the Sacchetti clan, the mathematician himself and perhaps also the other expats from Sicily, in that very specific political conjuncture, all happened to be gathered under the umbrella of the French "faction" and to be subjected to the influence of its agents in Rome. ${ }^{60}$

sored by Alessandro Falconieri (see above, note 23) —and the new edition of the Conics bound together with Archimedes' works, as two parts of the same book.

58 Elementa conica Apollonii Paergei et Archimedis Opera noua \& breuiori methodo demonstrata a Ioanne Alphonso Borellio (Romae: apud Mascardum, 1679), Eminentissimo et Reverendissimo S.R.E. Cardinali amplissimo D. Foelici Rospiglioso. As a sign of Felice's political alignment, it is worth mentioning here that in 1672 he-a nephew of the reigning Pope Clement IX's - let the Pope first appoint César d'Estrées cardinal, so as not to displease the French Court. He was therefore named cardinal deacon only in January ${ }_{16} 63$ (Irene Fosi, "Rospigliosi, Giacomo," in DBI, 88 [2017]). Even before being elected cardinal nephew by Clement IX, Giacomo too established excellent relations with the Court of Louis XIV during his career in the Roman Curia (ibid.).

59 Other family members are written in the will: the "Most Excellent Lord Duke Rospigliosi," that is Giovanni Battista, the youngest brother of Felice and Giacomo, who had been in charge of perpetuating the lineage after another brother, Tommaso, died in 1669 (Fosi, Rospigliosi). Borelli also recalled Giovanni Alberto Cellesi, maternal cousin of the brothers Rospigliosi and a former courtier of Tommaso (Francesco Calcaterra, La spina nel guanto: corti e cortigiani nella Roma barocca [Roma: Gangemi, 2004], 66n), as well as the Abbot Ippolito Nencini from Pistoia, who also had served at Tommaso's court (ibid.).

6o As soon as he was elected cardinal, in 168o, Urbano Sacchetti-whom we have seen among Borelli's legatees - confirmed the traditional pro-French policy of the family (Irene Fosi, "Sacchetti, Urbano," in DBI, 89 [2017]). Christina of Sweden had joined that party already in the 165 os - if, of course, from a far more independent position-, while Cardinal Decio Azzolini junior, who is also mentioned in Borelli's will probably because of his close relationship with the Queen, had been the secretary of State under Clement Ix (Marie-Louise Roden, Church Politics in Seventeenth-Century Rome: Cardinal Decio Azzolino, Queen Christina of Sweden, and the Squadrone Volante [Stockholm: Almqvist and Wiksell, 200o]; Gianvittorio Signorotto, "The squadrone volante: 'Independent' Cardinals and European Politics in the Second Half of the Seventeenth Century," in Court and Politics, 177-211). There are no specific studies on the fate of Messina exiles in Rome, nor on their political alignment after their expulsion from Provence and the Treaty of Nijmegen was signed (September 17, 1678) (Laloy, La Révolte, III, 769-771). In late 1700, after the election of Philip v first Bourbon King of Spain, the ones still settled in Rome-Mario Reytano among themappealed to Louis XIV asking for the new king to grant them the pardon (ibid., III, 823), what happened on May 13, 1702. 
Borelli's endorsement in Rome by families of Tuscan origin (Falconieri, Sacchetti, Rospigliosi) all raised in the past decades thanks to the pontificate of the Florentine Urban VIII, was perhaps facilitated also by his long-standing relationships with Michelangelo Ricci-a mathematician and a member of the Roman Curia - who was at that time a sort of informal representative of the Medici court both in the Pope's city and among the learned men. ${ }^{61}$ The "warm friendship and correspondence" ("cordiale amicizia e corrispondenza" $)^{62}$ between Borelli and Michelangelo Ricci, grounded as it was in sharing the credo in the 'true' philosophy, is all too well known. Both pupils of Benedetto Castelli in the ' 30 s, had been friends and correspondents since the years of activity of the Academy of the Cimento (1657-1667). ${ }^{63}$ Between 1658 and 1659 , Borelli wanted Ricci to have the ultimate revision of the translation from Arabic to Latin of the last lost books of the Conics of Apollonius done by Ecchellense. In 1667, after the Cimento dispersed, Ricci tried in vain to keep Borelli with him in Rome. ${ }^{64}$ Borelli was back in the Urbs in 1673 and after three years in which Lucantonio Porzio, now settled in Rome, had mediated their relations, ${ }^{65}$ they used to spend time together. ${ }^{66}$ Relations between

61 Francesco Bustaffa, Michelangelo Ricci (1619-1682). Biografia di un cardinale innocenziano (PhD Thesis, Scuola superiore di studi storici di S. Marino, 2010-2011), 313-316, and Id., "Ricci, Michelangelo," in DBI, 87 (2016).

62 See the letter by Ottavio Falconieri to Leopoldo de' Medici, Rome, March 28, 1665, in Ottavio Falconieri, Lettere ... a Leopoldo de' Medici nel Carteggio d'Artisti, ed. L. Giovannini (Florence, Edam, 1984), 126-127. The difference of opinion on Famiano Michelini's Trattato sulla direzione dei fiumi (1665) did not disturb these good relations for long (Bustaffa, Michelangelo Ricci, 167-168).

63 On Borelli's pivotal role in the Cimento's activities: Paolo Galluzzi, "L'Accademia del Cimento: gusti del principe, filosofia e ideologia dell'esperimento," Quaderni storici 48, no. 3 (1981): 788-844, and The Accademia del Cimento, passim.

64 Jean-Michel Gardair, Le "Giornale de Letterati” de Rome (1668-1681) (Florence: L.S. Olschki, 1984), 5 1n.

65 As the epistolary Borelli-Porzio edited by Giuseppe Mosca proves (Mosca, Vita, 81-96). Porzio had moved to Rome in 1670.

66 See, for instance, the letters: from Michel Angelo Ricci to Vincenzio Viviani, from Rome, on September 16, 1673 (BNCF, ms. Gal. 164, f. 29or), and from the same to Leopoldo de' Medici, from Rome, on February 2, 1675 (BNCF, ms. Gal 165, f. 199r). In those years, Ricci often acted in Rome on behalf of Viviani. He was probably the one who introduced Vincenzo Santini, one of Viviani's protegées whom he himself was tutoring in mathematics, to Borelli (see above, note 21). Ricci and Viviani are probably also responsible for the acquaintance between Borelli and "Father [Ippolito?] Porto, of the Society of Jesus," also mentioned in Borelli's will. Ippolito Porto (or Da Porto), and his brother Benedetto, both gentlemen from 
the two Galileans was certainly cemented by Borelli's choice of the Dominican friar Giacomo Ricci (1624-1703) - brother of Michelangelo and secretary of the Congregation of the Index-as his confessor. ${ }^{67}$ Both Michelangelo and Giacomo show among Borelli's legatees, alongside the Abbot Francesco Nazari, at the time lecturer of natural philosophy at Sapienza University and director of the Printing House attached to the Urban College of Propaganda Fide. In 1668 Nazari had founded in Rome with Michelangelo Ricci the first Giornale de'letterati published by Nicolangelo Tinassi, and since 1675 had directed the journal of the same name (at this stage printed by Benedetto Carraro), that resulted from the split of the first editorial board and which in 1679 ended its publications for good. ${ }^{68}$ Although distant from Rome, Borelli had been a reader and contributor to the first Giornale, which in turn had favorably reviewed each of his works. ${ }^{69}$

The biographical records on Borelli gathered by Giovanni Targioni Tozzetti explain the presence of the archeologist Raffaello Fabretti from Urbino (16201700) in this list. ${ }^{70}$ According to the Danish physician Caspar Bartholin the younger (1655-1738), who in late November 1676 settled in Rome for a while during his "peregrinatio medica," Borelli used to meet at the time with Fab-

Vicenza, took part in the mathematical challenge that led Viviani to publish the Diporto Geometrico in 1676 (Antonio Favaro, Amicie Corrispondenti di Galileo, 3 vols. [Florence: Salimbeni, 1983], II, 1007-1165: 62-65; Luigi Tenca, "Le relazioni fra Giovanni Alfonso Borelli e Vincenzo Viviani," Rendiconti dell'Istituto Lombardo di scienze e lettere. Classe di scienze matematiche e naturali 9o, no. 1 [1956], 107-121).

67 The information results from the Preface to Borelli, De motu animalium ... opus posthumum, pars prima (Romae: ex typographia Angeli Bernabò, 168o), p. n. num., signed by Father Carlo Giovanni Pirroni, where this is listed among the evidence of Borelli's strong and sincere Catholic faith. On Giacomo Ricci (Lorenzo in the world), see Vincenzo Lavenia, DBI, 97 (2016), and Bustaffa, Michelangelo Ricci, passim.

68 Gardair, Le "Giornale de Letterati", passim. On Nazari, see, ibid., 73-97; Giorgio Panizza, "Francesco Nazari, estensore del primo giornale romano," Studi secenteschi 24 (1983): 155; Candida Carella, "I lettori di filosofia naturale della 'Sapienza' di Roma: $\mathrm{I}^{\circ}$ Francesco Nazari," Nouvelles de la République des Lettres 1 (2003): 7-35; Ead., "L'aetas galileiana in Sapienza," in Galileo e l'acqua, ed. Lucio Ubertini, Piergiorgio Manciola, and Arnaldo Pierleoni (Perugia: Grifo, 2010), 47-81.

69 Gardair, Le 'Giornale', 170-171, 190-193. In 1671, Borelli had the Giornale delivered to Messina through Lucantonio Porzio (Mosca, Vita, 81-96).

70 A clergyman, Fabretti worked at the time in the records office of the Cardinal Vicar of Rome, Gaspare Carpegna, and had been appointed 'watchman of the holy relics and cemeteries' by the latter. See: Massimo Ceresa, "Fabretti, Raffaello," in DBI, 43 (1993); Matteo Luni, Raffaello Fabretti "archeologo" urbinate: principe della romana antichità (Urbino: Accademia Raffaello, 2001); Harry B. Evans, Aqueduct Hunting in the Seventeenth Century: Raffaello Fabretti's De aquis et aquaeductibus veteris Romae (Ann Arbor: University of Michigan Press, 2002). 
retti and the Dalmatian historiographer, philologist and antiquarian Giovanni Lucio (1604-1679) at the bookshop "all'insegna della Nave," to chat about literary novelties and "other public matters."71 The bookshop, run by the printer and publisher Zenobi Masotti, in 1676 was located in Pasquino square, only a block away from San Pantaleo. ${ }^{72}$ (Fig. 4) Lucio had been a regular visitor of the conversation held "Alla Nave" for years. In late 1665 , there for instance, he learned that unexpectedly his masterpiece — the De Regno Dalmatiae et Croatiae — had finally been printed in Amsterdam. ${ }^{73}$ Lucio, who was a member of the editorial board of the first Giornale as well as Nazari's employer, had died in early $1679 ;{ }^{74}$ but in 1675 he, along with Fabretti, who was working on a new description of the Trajan column, could have provided Borelli with references when he was

71 "Fra le lettere di Gaspare Bartolino l'Iunione, figlio di Tommaso scritte ad Antonio Magliabechi [...], trovo memoria, che il Borelli frequentava il Crocchio Letterario, che si teneva in una bottega di librario di Roma; poiché in una lettera in data Romae. 6 Novembris A. 1676 dice il Bartolino: Cum Borello, Fabretto, Luccio, convenio apud Bibliopolam ad insigne Navis, ubi quotidie horam unam, vel alteram constitutam habent, quibus non minus negocia literaria, quam alia publica ventilantur ..." [Among the letters by Gaspare Bartolino Iunione, Tommaso's son, written to Antonio Magliabechi [...], I find recollection that Borelli used to attend the literary club held at a bookshop in Rome, because, in a letter dated Rome, November 6th Y. 1676 the Bartolin says: Imet with Borelli, Fabretti, Lucio at a bookshop 'at the Ship', where at any fixed time everyday both literary subject and public matters were debated] (Gio. Targioni Tozzetti, Notizie degli aggrandimenti delle scienze fisiche accaduti in Toscana nel corso di anni LX del secolo XVII [Florence: Giuseppe Bouchard, 1780], I/II, 217-218). On the "medical tour" as a tradition for the members of the Bartholin dynasty, see: Andrew Cunningham, "The Bartholins, the Platters and Laurentius Gryllus: The peregrinatio medica in the Sixteenth and Seventeenth Centuries," in Centres of Medical Excellence? Medical Travel and Education in Europe, 1500-1789, ed. Andrew Cunningham, Ole Peter Grell, and John Arrizabalaga (London: Routledge 2010), 3-16. The Giornale de' letterati (before and after the 1675 split) payed much attention to Caspar Bartholin junior's works (Gardair, Le 'Giornale', 340 and ad indicem).

72 Saverio Franchi, Le impressioni sceniche: dizionario bio-bibliografico degli editori e stampatori romani e laziali di testi drammatici e libretti per musica dal 1579 al 1800 (Rome: Edizioni di Storia e letteratura, 1994), 540-542. It is worth mentioning here that Masotti, then in partnership with Biagio Diversini, in 1651 had played a role in the printing process and marketing of the Tesoro Messicano, the apotheosis of the activity of the first Accademia dei Lincei (Franca Petrucci Nardelli, "Un illustre mostro tipografico: il Tesoro Messicano," Rara volumina 1 [1998]:37-71; Ebe Antetomaso, "Il censimento degli esemplari del Tesoro messicano: nuovi esiti di un'indagine bibliologica," in Il Tesoro Messicano: librie saperi tra Europa e Nuovo mondo, ed. Maria Eugenia Cadeddu and Marco Guardo [Florence: L.S. Olschki, 2013], 93-132).

73 Vitaliano Brunelli, “Giovanni Lucio (1899)," in Giovanni Lucio, Storia del Regno di Dalmazia e di Croazia (Trieste: LINT, 1983), 23-24 and n.

74 Gardair, Le 'Giornale', 86, 99-102. On the relationships between Ricci and Lucio, see also Bustaffa, Michelangelo Ricci, 176 and $\mathrm{n}$. 


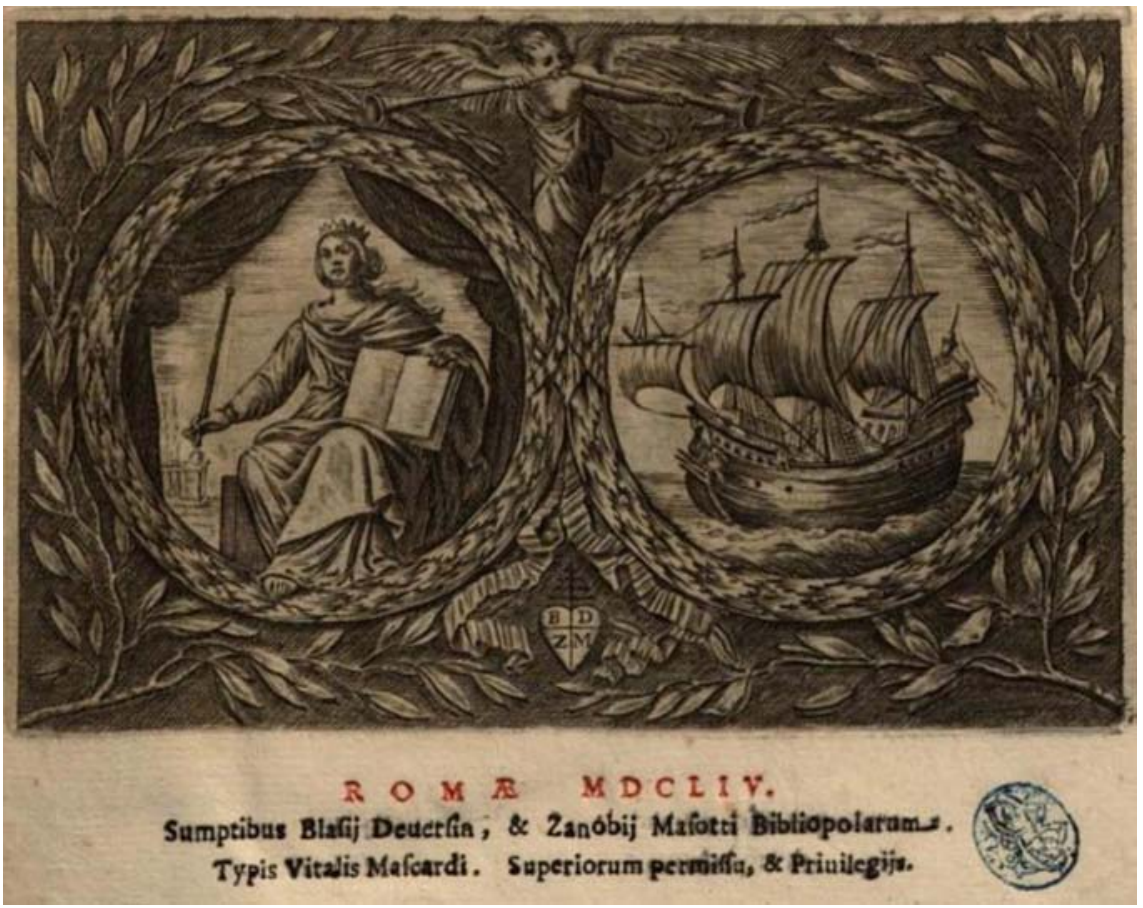

FIGURE 4 Sign of Zanobi Masotti' bookshop "all'insegna della Nave" (right), from the frontispiece of Athanasius Kircher, Magnes siue De arte magnetica (Romae: sumptibus Blasij Deuersin, \& Zanobij Masotti bibliopolarum. Typis Vitalis Mascardi, 1654)

commissioned to dispute against the antiquarian Francesco Cameli at Queen Christina's Royal Academy on the alleged structure of the ancient triremes. ${ }^{75}$

75 The text of Borelli's talk in BAv, Ottob. lat. 1744, ff. 95r-104v. On it, Edward Knowles Middleton, "Giovanni Alfonso Borelli on the Construction of Galleys," The Mariner's Mirror 59, no. 1 (1973): 3-8. Fabretti had been working since the early 1670's to his Syntagma de columna trajana (Romae: ex officinâ Nicolai Angeli Tinassij, 1683), where chapter 5 deals with the functioning of the triremes depicted on the frieze (Ingo Herklotz, "Bellori, Fabretti, and Trajan's Column," in Art History in the Age of Bellori: Scholarship and Cultural Politics in Seventeenth-Century Rome, ed. Janis Bell and Thomas Willette [Cambridge:Cambridge University Press, 2002], 75-93; Mirco Modolo, Illustrare l'historia Romana. Caratteri e finalità della ricerca antiquaria nelle opere di Bellori e Bartoli [Torino: Collana Alti Studi sull'Età e la Cultura del Barocco-Fondazione 1563, Torino, 2018], 99-107). Giovanni Lucio took up on the issue at the 1st January 1678 meeting of the Accademia fisicomatematica of Giovanni Giustino Ciampini (BAV, ms. Ottob. Lat. 3052, ff. 28v-29v). On this subject see: Federica Favino, Borelli and the Ancient Triremes: Antiquarianism and Political Commitment, forthcoming. 
Network historical research applied to Borelli's last will, taken as a "socio-text," portrays the philosopher at the very center of several, different overlapping networks: lay noble patrons (Queen Christina of Sweden, the members of the Sacchetti clan), clerical patrons (the cardinals Rospigliosi with their clan); pupils (Vincenzo Santini and the Falconieri brothers), party comrades (Antonio and Mario Reytano, Giovanni d'Arces, Pietro Faraone), free thinkers on the natural world (Lucantonio Porzio, Michelangelo Ricci, Francesco Nazari), as well as "Cartesian archeologists" (Raffaele Fabretti, Giovanni Lucio). ${ }^{76}$ If we widen our gaze on this scenario, the different networks appear even intertwined around a few nodes: the King of France and his representatives in Rome (Christina of Sweden, Borelli and the expats from Messina, the cardinals Rospigliosi and Sacchetti, Francesco Nazari), Michelangelo Ricci (Giacomo Ricci, Lucantonio Porzio, Francesco Nazari, Giovanni Lucio, Raffaele Fabretti), the Gran Duke of Tuscany (the Sacchetti and Falconieri clans) and Cardinal Leopoldo de' Medici (Vincenzo Santini, Michelangelo Ricci).

Reconstructing the plot of the personal relationships that bound Borelli with his legatees, and his legatees to one another also sheds light on the editorial strategy followed by Borelli in his later years: the illusion that the King of France would become a powerful patron for himself and a sponsor for his masterpiece; the failure of this strategy, that went parallel with the strategy pursued by the ambassadors of the Messina Senate in revolt in search for protection against the Spaniards; the settlement for a network of local patrons in Rome who were clients of d'Estrées brothers and Queen Christina's final decision to bear the printing costs of the De Motu. ${ }^{77}$

76 Both Lucio and Fabretti had a "experimental" approach to archeology. On Fabretti see: Elena Vaiani, "Raffaele Fabretti, il "Signor Censore": Una polemica antiquaria sui medaglioni di Gaspare Carpegna," Studi secenteschi 46 (2005): 211-228; Danilo Mazzoleni, ed., Raffaele Fabretti, archeologo ed erudito. Atti della giornata di studi, 24 maggio 2003 (Città del Vaticano: Pontificio istituto di archeologia cristiana, 2006); Elena Vaiani, "Lettere di Raffaele Fabretti ad Antonio Magliabechi," Studi secenteschi 48 (2007): 311-354. According to the biographer Vincenzo Leonio, Giovanni Giustino Ciampini-who had a strong interest both in natural philosophy and Christian archeology — would have learnt from Lucio to analyze ancient remains through the "ocular experiment," that is, by comparing historical and iconographic sources ("Vita di Monsig. Gio. Giustino Ciampini romano detto Immone Oeio," in Le vite degli Arcadi illustri, ed. Giovan Maria Crescimbeni [Roma: de Rossi, 1710], 195-254). An assessment of this source in: Renata Ago, Tanti modi per promuoversi: Artisti, letterati, scienziati nella Roma del Seicento (Roma, 2014), 56-61, doi: 10.14615/enbach49.

77 This sequence of events can explain why the dedicatory epistle to Cristina that Borelli prefaced to the De Motu was quite dry (Antonio Clericuzio and Maria Conforti, “Christina's 
The social configuration of Borelli's last network is food for thought also for an absence and an intriguing circumstance. Antonio Oliva-the natural philosopher who had been a member of the Accademia del Cimento in the same years as Borelli and with whom he had shared the philosophical assumptions of Galileo's mechanics - is unexpectedly missing from Borelli's will. Oliva had left Florence in 1667 (soon after Borelli) and moved to Rome, where he hoped to take advantage from the patronage of the new Pope, Clement IX Rospigliosi, whose young nephew Tommaso, had been tutored by Antonio Oliva. ${ }^{78}$ In 1679 , Oliva was still living in Rome, now under the protection of Lorenzo Onofrio Colonna, the Grand Constable of the Kingdom of Naples and a leading figure among the pro-Spain aristocracy in Rome, who was not involved in any of the clusters we singled out, perhaps because of political reasons. ${ }^{79}$

Such socio-political alignments could also explain why Borelli was never inducted into the Academy of Physico-matematics established by the prelate and learned man Giovanni Giustino Ciampini in Rome in 1677, with the intent to replicate the research agenda of the Cimento experimenters. ${ }^{80}$ In a huge biography of Michelangelo Ricci, Francesco Bustaffa suggested that the editorial board of the first Giornale de' Letterati split in 1675 not as a consequence of divergent epistemological options, as put forward by Antonella Romano, ${ }^{81}$ but

Patronage of Italian Science: A Study of her Academies and of the Dedicatory Epistles to the Queen," in Sidereus Nuncius \& Stella Polaris. The Scientific Relations Between Italy and Sweden in Early Modern History, ed. Marco Beretta and Tore Frängsmyr [Canton: Science History Publications, 1997], 32).

78 Ugo Baldini, Un libertino accademico del Cimento:Antonio Oliva (Florence: Istituto e Museo di storia della scienza, 1977), 43-47; Federica Favino, "On the Cimento's Oak Academies: An Unknown Contribution by Antonio Oliva," in Accademia del Cimento, 91-119; Vincenzo Lavenia, DBI, 79 (2013), s.v.

79 On Lorenzo Onofrio Colonna, see: Gino Benzoni, DBI, 82 (1987), s.v. Ugo Baldini conjectures on Oliva's political credo in relation to Colonna in Un libertino accademico del Cimento, 49-5o. On Colonna's role within the Roman noble families faithful to the Spanish crown, see also: Oliván Santaliestra, Nithard en Roma, 589-590.

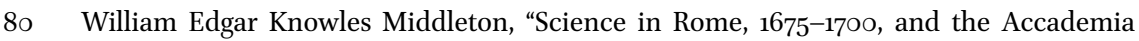
fisicomatematica of Giovanni Giustino Ciampini," The British Journal for the History of Science 8 (1975): 138-154; Salvatore Rotta, "L'Accademia fisico-matematica Ciampiniana: un'iniziativa di Cristina?", in Cristina di Svezia: Scienza ed alchimia nella Roma barocca (Bari: Dedalo, 1990), 99-174; Federica Favino, "Beyond the 'Moderns'? The Accademia Fisico-matematica of Rome (1677-1698) and the Vacuum," in "The Circulation of News and Knowledge in Intersecting Networks," ed. Sven Dupré and Sachiko Kusukawa, History of Universities 23, no. 2 (2008): 120-158; Donato, Late Seventeenth-Century Scientific Academies, 157-159.

81 Antonella Romano, "I problemi scientifici nel "Giornale de' Letterati” (1668-1681)," Dimensioni e problemi della ricerca storica 8, no. 1 (1997): 17-37. 
for reasons of political dissent. While Nazari-who in Borelli's network appears alongside his patron Cardinal Gregorio Barbarigo ${ }^{82}$ — was at the time very close to Cardinal d'Estrées, the other co-director Ciampini was shifting to the political positions of the Curial party which supported Pope Innocent XI's strict policy towards Gallicanism and Probabilism, against the interests of the French court. ${ }^{83}$ Perhaps, it was this "factional conflict" that allowed Borelli to talk about the construction of the triremes of the ancients at Christina's court- that Ricci considered a waste of time that distracted Borelli from his studies ${ }^{84}$ - but prevented him from joining the discussions on the vacuum at Ciampini's place, a subject which would have suited him much better.

Overall, the document returns a portrait of Borelli that is consistent with his whole life and work. The legacy — the De motu—is the epitome of the latter, the masterpiece from which a sense of identity, self-respect, and personal fulfillment easily derived..$^{85}$ The choice of legatees confirms his stance towards 'true philosophy' and the political freedom to exercise it.

82 Gregorio Barbarigo (1625-1697), Roman Catholic cardinal (1660) who served as the Bishop of Padua. In 1663 he had introduced Nazari to Ricci, whom he had met in Rome in the mid ' 5 os, sharing with him mathematical interests. After the election of Pope Innocent XI (1676), Barbarigo settled in Rome until 168o. Still close to Nazari, in those years he was more and more distancing himself from the Curial party and from the supporters of spiritual tendencies (later labeled as quietist), including Michelangelo Ricci. References on Barbarigo include: Gino Benzoni, DBI, 59 (2002); Liliana Billanovich and Pierantonio Gios, eds., Gregorio Barbarigo patrizio veneto vescovo e cardinale nella tarda Controriforma (16251697). Atti del convegno di studi (Padova, 7-10 novembre 1996), 2 vols. (Padova: Istituto per la storia ecclesiastica padovana, 1999); Pio Pampaloni, ed., Gregorio Barbarigo alla corte di Roma (1676-1680). Lettere familiari e di governo (Padova: Istituto per la storia ecclesiastica padovana, 2009).

83 Bustaffa, Michelangelo Ricci, 313-316. On the events that made Nazari almost an attaché of French diplomacy in Rome, from late 1675: see also Panizza, Francesco Nazari estensore, 164-168; Gardair, Le “Giornale", 8o-81, 88-9o; Bustaffa, Michelangelo Ricci, 308-313.

84 See the letter from Michelangelo Ricci to Leopodo de' Medici, March 26, 1675, in Lettere inedite di uomini illustri per servire d'appendice all'opera intitolata Vitæ Italorum doctrina excellentium, ed. Angelo Fabroni (Florence: nella stamperia di Francesco Moücke, 1775), II, 198.

85 Keith Thomas, The Ends of Life. Roads to Fulfilment in Early Modern England (Oxford: Oxford University Press, 2009). See also: Michael Mascuch, Origins of the Individualist Self. Autobiography and Self-Identity in England, 1591-1791 (Cambridge: Polity Press, 1997); Adam Smyth, Autobiography in Early Modern England (Cambridge: Cambridge University Press, 2010). 


\section{Acknowledgments}

This research has received funds by the European Union's Horizon 2020 research and innovation programme under the Marie Skłodowska-Curie grant agreement No 799769. A first draft of this text was presented at the workshop Science, Politics and Faith in the Seventeenth Century: The World of the Galileans, held at Stanford University of February 7, 2020. I want to thank Mario Biagioli, Antonio Clericuzio, Maria Conforti, Simon Dumas Prinbault, Paula Findlen, Giulia Giannini, Massimo Mazzotti, J.B. Schank and all the participants for their valuable comments. I wish to thank the editors and the anonymous reviewers for the many valuable suggestions that helped me improve the text.

\section{Testamentum D. Jo. Alphonsi Borelli ${ }^{86}$}

Die trigesima prima Xmbris 1680: a Nat[ivitat]e

In meis D. Jo: Alphonsus Borellus filius q[uondam] Michaelis, et Laurae de Civ[itat]e Neapolis mihi $\operatorname{cog}[$ nitus] sanus omnipotentis Dei gratia mente, sensu, loquela, auditu, visu, et intellectu, ceterisque sensibus, licet corpore languens in lecto iacens, timens casum suae futurae mortis, cum nil [!] sit certius ea, et nil [!] incertius hora, et punctum illius, nolens intestatus decedere, sed de rebus et bonis suis disponere ne inter suos posteros aliqualis seu controversia oriatur, Idcirco] hoc i[nstrument]um $\mathrm{p}$ [raese]ns suum ultimum nuncupatum test[ament]um, quod de iure civili dicit[ur]. Sine scriptis condere deliberavit; prout sponte, ac omni mel[iori] modo fecit et condidit. In hunc qui sequitur modum, et formam $\mathrm{v}[\mathrm{i}] \mathrm{d}[\mathrm{e}]$ licet

Primo igitur incipiendo ab anima tanquam [!] corpore nobiliori, ill[am] omni qua[...] devotionem commendavit et commendat omnipotenti Deo eiusque S[ancitssi]mae Matri Mariae eorumque caelesti Curiae corpus vero suum quando ab anima separari contigerit humari et seppelliri voluit, aut in Ven[erabil]i Eccl[esi]a S[an]cti Pantaleonis Scholarum Piarum de Urbe, ${ }^{87}$ aut in Ven[erabil]i Eccl[es]ia S[anct]i Laurentii Novitiatus Ven[erabil]is Religio-

86 AsR, Uffici della Curia del card. Vicario, Ufficio 32, vol. 257, cc. 476r-478v. The transcript is true to the original. Abbreviations have been spelled out. The three dots indicate signs difficult to read.

87 The Church of San Pantaleo, adjacent to the convent of the Piarists Fathers, in the Parione neighborhood. Borelli was in fact buried there. 
nis Pauperum Matris Dei Scolarum Piarum par[iter] de Urbe ${ }^{88}$ ar[bi]t[ri]o Rev[erendissi]mi P[atris] Praepositi G[e]n[era]lis in dictae ven[erabilis] Religionis, cui quidem Ecclesiae ubi humaverit iura sepulturae $\tan [. .$.$] reliquit$ omni etc.

Item dichiara esso testatore che havendogli donato la sagra maestà della Regina di Svezia ${ }^{89}$ doble Cento ad effetto di far stampare un libro da esso testatore composto intitolato De motu Animalium; ${ }^{90}$ per tanto vuole, et intende che del prezzo di d[ett]i libri, subito che sarranno stampati, la cura della qual stampatura la rimette al Rev[erendissi]mo P[ad]re Carlo Giovanni di Giesù ${ }^{91}$ Preposito Generale di d[ett]a Religione, se ne debbano prima sottrarre scudi cinquanta mon[et]a quali per raggion di legato, et in ogn'altro meglior modo li lascia al Sig[no]r Lorenzo di Tomaso ${ }^{92}$ suo medico per li molti, et accurati servitij che ha usati in questa sua infermità, et altri scudi trenta al S[igno]r dottor Luca Antonio Porzio ${ }^{93}$ parim[en]te medico che ha assistito in d[ett]a sua infermità, e detta quantità di denaro sia in arbitrio d'essi legatarij di prenderselo o in tanti libri della d[ett]a opera da stamparsi, opure in denari contanti, come meglio ad essi, e ciascheduno d'essi loro parerà.

$\mathrm{It}[\mathrm{em}]$ Per raggione di legato, et in ogn'altro meglior modo, lascia alla $\mathrm{d}[\mathrm{ett}] \mathrm{a}$ Sagra Maestà della Regina di Svetia Sua Sig[no]ra Colendiss[im]a tutto quel numero d'esemplari che piaceranno a Sua Maestà ad effetto di distribuirli alli [c. 477r] Sig[no]ri letterati d'Europa fra i quali in primo luogho vuole, e dichiara che debbiano essere ammessi li Sig[no]ri Accademici di Sua Maestà.

It $[\mathrm{em}]$ per raggion di ligato come s[opr]a lascia alli Sig[no]ri figlioli maschi del Sig[no]r Paolo Franc[esc]o Falconieri, ${ }^{94}$ et al Sig[no]r Vincenzo Santini ${ }^{95}$ loro maestro due delli d[ett]i libri da stamparsi per ciascheduno, et un altro al $\mathrm{P}[\mathrm{ad}] \mathrm{re}$ Porto della Compagnia di Giesù. ${ }^{96}$

88 This is the 12th-century small church of S. Lorenzo in Piscibus, in the Borgo Santo Spirito, assigned to the Piarist Fathers from 1663 .

89 Queen Christina of Sweden (1626-1689), Borelli's patron, sponsor and dedicatee of his De Motu.

90 Borelli, De motu animalium ... opus posthumum (Romae: ex typographia Angeli Bernabò, 1680-1681).

91 Carlo Giovanni Pirroni di Gesù (1640-1685), Procurator General of the Piarists' Order since 1673 and editor of the De Motu.

92 Lorenzo di Tommaso ( $\nmid 1685$ ?), apothecary from Messina, good friend of Borelli and Malpighi, involved in the Anti-Spanish Revolt of 1674-1678.

93 Lucantonio Porzio (1639-1723), medical doctor and natural philosopher.

94 Lelio (1655-1717) and Alessandro (1657-1734), sons of Paolo Francesco Falconieri (16261696).

95 Florentine Mathematician (1652 ca.-1722 ca.), priest and tutor of the brothers Falconieri.

96 Ippolito Porto (or Da Porto) of the Society of Jesus, a gentleman from Vicenza settled in the Collegio Romano. Brother of Count Benedetto, one of Viviani's correspondents. 
It[em], per raggioni di legato come sopra lascia all'Em[inentissi]mi e Rever[endissi]mi Sig[no]ri Card[ina]li Giacomo, ${ }^{97}$ e Felice de Rospigliosi, ${ }^{98}$ Barberigo, ${ }^{99}$ et Azzolini, ${ }^{100}$ et anco all'Ecc[ellentissi]mo Sig[no]r Duca Rospiglio$\mathrm{si}^{101}$ uno delli sopradetti libri per ciascheduno.

It $[\mathrm{em}]$ per raggioni di legato come sopra lascia alli Sig[no]ri Gio Alberto Cellesi, ${ }^{102}$ Ippolito Nencini, ${ }^{103}$ Franc[esc]o Nazzarij, ${ }^{104}$ Sig[no]r Marchese Theodoli, ${ }^{105}$ marchese Nerli, ${ }^{106}$ marchese Sacchetti, ${ }^{107}$ monsig[no]r Sacchetti, ${ }^{108}$ Sig[no]r Cavalier Sacchetti, ${ }^{109}$ Sig[no]r Raffael Fabretti, ${ }^{110}$ Sig[no] r Abb[at]e Michel Angelo Ricci, ${ }^{111}$ et al P[ad]re Ricci suo fr[at]ello dell'Ord[in]e de Predicatori, ${ }^{112}$ Sig[no]ri Antonio Reytano e Furnari, ${ }^{113}$ Sig[no]r Giovanni d'Arges, ${ }^{114}$ e D[on] Pietro Farraone, ${ }^{115}$ et anco a tutti i suoi scolari di Roma sia religiosi, come secolari, uno delli soprad[ett]i libri da stamparsi come s[opr]a.

Giacomo Rospigliosi (1628-1684), Italian Roman Catholic cardinal (1667), cardinal-nephew to Pope Clement IX.

98 Felice Rospigliosi (1639-1688), Italian Roman Catholic cardinal (1673), Giacomo's younger brother.

99 Gregorio Barbarigo (1625-1697), Italian Roman Catholic cardinal (1660) and the bishop of Padua.

100 Decio Azzolini jr. (1623-1689), Italian Roman Catholic cardinal (1654), leader of the "squadrone volante" (faction of independent cardinals), secretary of State under Pope Clement IX, Queen Christina's best friend and advisor.

101 Giovanni Battista Rospigliosi (1646-1722), Duke of Zagarolo, youngest brother of Giacomo and Felice.

102 Giovanni Alberto Cellesi, maternal cousin of the brothers Rospigliosi, who had served as a courtier of their brother Tommaso Rospigliosi (who had died in 1669), the former Duke of Zagarolo.

103 Ippolito Nencini, former courtier of Tommaso Rospigliosi.

104 Francesco Nazari, abbot from Bergamo, superintendent to the Polyglot printing press of the Congregation of Propaganda Fide (1669), lecturer of natural philosophy at Sapienza University (1670), co-editor of the first Giornale de'Letterati (Tinassi, 1668-1675) and editor of the Giornale de' Letterati printed by Benedetto Carraro (1675-1679).

105 Carlo Maria Theodoli (1633-1697), Marquis of San Vito and Pisoniano.

106 Filippo Nerli (1639-1712), Marquis of Resina.

107 Giovanni Battista Sacchetti (1639-1688), Marquis of Castel Rigattini.

108 Urbano Sacchetti (1640-1705), clerks of the Apostolic Chamber.

109 Marcello Sacchetti (1644-1720), knight of justice of the Order of Malta.

110 Raffaele Fabretti (1620-1700), archaeologist and antiquarian.

111 Michelangelo Ricci (1619-1682), Italian mathematician and Curial officer.

112 Giacomo Ricci (1624-1703), Dominican friar, secretary of the Congregation of the Index.

113 Antonio Reytano e Furnari, Baron of S. Pietro, gentleman from Messina, member of the Messina Senate, involved in the Anti-Spanish Revolt of 1674-1678.

114 Giovanni d'Arces, gentleman from Messina, involved in the Anti-Spanish Revolt of 16741678.

115 Pietro Faraone, gentleman from Messina, leader of the Anti-Spanish Revolt of 1674-1678. 
Item per raggion di legato come s[opr]a lascia al sopradetto Sig[no]r Vincenzo Santini ${ }^{116}$ il suo quadrante, e l'occhialone.

In omnibus ante[...], et singulis suis bonis, tam mobilibus, quam stabilibus libris scriptis iuribus, et actionibus quibuscumque debitorum nominibus, tam praesentibus, quam futuris [quibus] vis locorum positis, et existentibus, et sub quibusvis finibus confinatis ad Ipsum modo, et pro tempore spectantibus et pertinent[ibus] suam heredem universalem fecit instituit, ordinavit ac ore proprio nominavit Ven[erabile]m Domum S[ancti] Pantaleonis eiusque d[ict]ae Religionis Scolarum Piarum de Urbe, cui universam eius haereditatem reliquit omni etc.

Et execuutorem, huius ultimae suae voluntatis et dispositionum D[ominus] Testator elegit et deputavit Rev[erendissi]mum P[at]rem Paepositum Generalem D[ict]ae Ven[erabilis] Religionis, ${ }^{117}$ cui tribuit et concessit omnes et singulas facultates, et authoritates necessarias, et opportunas, etiam declarandi dictam suam ultimam voluntatem et omnia alia in supradicto eius testamento contenta non solum sed omni etc.

Et hoc d[ictus] D[ominus] testator esse voluit eius ultimum testamentum, eiusque ultimam voluntatem quod, et quam valere voluit iure testament[orum] nuncupat[orum] sine scriptis, et si tali iure non valeret valere voluit iure codicillorum, donationis causa mortis aut alt[eriu]s huiuscumque ultimaeque voluntatis, et dispositionis, cassans proposita [...] et annullans omnem, et quodcumque alium testamentum omnemque aliam ultimam voluntatem et dispositionem per ipsum usque in $\operatorname{pr}[$ aesent]em diem conditum, et factum per acta cuiusvis notarij et sub quibusvis verbis derogatorijs, derogatariarum, derogatarijs volens quod praesentibus omnibus praeferatur non solum praemisso, verum etiam; et omni meliori modo etc. sub quibus etc.

Actum Romae in d[ict]a Ven[erabili] Domo S[ancti] Pantaleonis, et proprie in mantione $\mathrm{p}[\mathrm{rae}] \mathrm{d}[\mathrm{ict}] \mathrm{a} \mathrm{d}[\mathrm{ict}] \mathrm{o}$ testatore inhabitata $\mathrm{p}[$ raese $]$ ntibus

1. Ill[ust]itis[sim]o Josepho de Julij filio q.Joannis de Terra Pharae S. Martini nullius diocesis

2. D. Jo: Bapt[is]ta Liberato filio q[uondam] Jacobi Rom[anu]s

3. D. Caietano Stephani filio D. Dom[ini]ci Romanus

4. D. Dominico Barcato filio q[uondam] Antonij Rom[anu]s

5. D. Bernardino Gombi filio D. Matthei de Regio, mutinensis diocesis

6. D. Jo. Bapt[ist]a Cappello filio q[uondam] Gaudentij Ariminensis, et

7. D. Petro Vangorio filio q[uondam] Fran[cisc]i Bergomens[is] testibus

116 See supra, n. 23 .

117 That is Carlo Giovanni Pirroni (see supra, n. 14). 
Eadem die ac successive

Sup[erscript]us D. Jo: Alphonsus Borellus coram sup[erscrip]tibus testibus $\mathrm{d}[\mathrm{ixi}] \mathrm{t}$, et declaravit ipsum in eius posse habere, et retinere caedulam Banci $\mathrm{S}$. $\mathrm{Sp}$ [irit]us in Saxia de Urbe scutorum duorum millium, et quatringentorum mon[e]t[ae] existen[tem] in creditum D. Marij Reitani et furnari filij D. Antonini Reitani, eiusque dispositionem uti illius Proc[urator]is, et in ea ipsum D. Borellum nullum ius, nec interesse habere, et ita etc. non solum etc. sed omni etc. super quibus etc. 